\title{
A comparative study on the expression profile of aquaporin 3(AQP3) gene in the skin fibroblast cells of Barbari and Sirohi breeds of goat
}

\author{
Femi Francis, Ashutosh and Thulasiraman Parkunan
}

Received: 02 February 2020 / Accepted: 25 February 2020 / Published online: 18 May 2020

(c) Indian Dairy Association (India) 2020

\begin{abstract}
Lack of availability of good quality and quantity of water affects the physiology of goats. Goats may adapt to thrive well in water deficit areas by making alterations in the expression of aquaporin (AQP) genes for their efficient water use. The current study was carried out in skin fibroblast cells of Barbari and Sirohi goats. Under in vitro conditions, during different temperatures and osmotic treatments, variations in relative expression of AQP3 genes were observed. At higher temperatures the relative expression of AQP3 genes in Sirohi breed was found to be significantly higher $(\mathrm{p}<0.01)$ than Barbari breed. However, during hyperosmotic concentration at normal temperatures the relative expression of AQP3 mRNA was significantly $((p<0.05)$ increased in both the breeds. During a high temperature combination with hyperosmotic concentration in cell culture of skin fibroblast cells the relative expression of AQP3 mRNA was increased in Sirohi breed $(\mathrm{p}<0.01)$ whereas it decreased in Barbari goat's breed. The variations in AQP3 gene expression during water stress condition and during hyperosmotic concentrations of skin fibroblasts cell culture suggests the positive involvement of AQP3 gene in maintaining the water balance in the body.
\end{abstract}

Keywords: AQP3, Barbari, Sirohi, Hyperosmotic,Skin fibroblasts

Femi Francis, Ashutosh

Animal Physiology Division, ICAR - National Dairy Research Institute (NDRI), Karnal-132 001, Haryana, India

Thulasiraman Parkunan $(\square)$

Department of Veterinary Physiology \& Biochemistry, Faculty of Veterinary and Animal Sciences, Institute of Agricultural Sciences, Banaras Hindu University, Barkachha, Mirzapur, Uttar Pradesh, India

E-mail: dr.thula89@gmail.com

\section{Introduction}

Global water scarcity is expected to be intensified in the future by a number of emerging threats such as growing world population and climate change. Many areas of the world that have already experienced shortage of water resources will further worsen their water issues, causing hardships for sustaining the livelihood. According to the United Nations World Water Development report 4, by 2025, about 1.8 billion people will live in areas affected by water scarcity, with two-thirds of the world's population living in water-stressed regions (UNESCO, 2012). Livestock production is widely considered as an intensive water consuming activity (Molden et al. 2010). Compared to the total water usage in livestock production systems, water for livestock consumption is proportionately small in amount but is an important requirement for health and productivity of animals (Amenu et al. 2013). In addition, lack of sufficient source of water can be a critically limiting factor in affecting the normal physiology and productivity (Alamer M, 2010).

Goats are known as poor man's cow because of its vast contribution to the rural economy. With 115.3 million goat population, India stands second in goat production in the world in which a major proportion of goat $(>70 \%)$ thrives in arid and semiarid areas of western region and southern peninsular region of India (Sejian et al. 2012). Arid zones are characterized by excessive ambient temperatures, low humidity, low soil moisture and insufficient and erratic pattern of precipitation. In many countries like India with arid zones, high environmental temperatures during summer seasons may last up to 6 months, with average temperatures over $30^{\circ} \mathrm{C}$ (Avendano-Reyes, 2012). This is important because a high proportion of the goat population lives in these areas where water requirements are not easily met. Breeds of goats in arid and semi- arid zones are well adapted to survive in these water deficit areas. It has been well established fact that even though livestock including goats require large quantities of water for maintaining their body functions, some of the breeds which have evolved and naturally developed in arid regions, survive and remain to be productive with less water intake at higher temperatures. 
Aquaporin proteins (AQP) are known as the plumbing system of the cell and act as water channels across the cell. Aquaporin proteins have been identified in different plants (Johansson et al. 2000; Schaffner 1998) and animals (Agre et al. 2002; Agre and Kozono, 2003; King et al. 2004). So far, thirteen isoforms of Aquaporin (AQP0- AQP12) have been discovered. Aquaporin proteins are broadly classified into two groups known as orthodox aquaporins (AQP 1, 2, 4, $5 \& 8$ ) that selectively transport water and the aquaglyceroporins (AQP 3, 7, $9 \& 10$ ) that transports small solutes along with water. Among all the aquaporin proteins, $\mathrm{AQP} 1, \mathrm{AQP} 3$ and $\mathrm{AQP} 5$ are widely expressed in skin tissues and found to play an important role in normal skin physiology (BouryJamot et al. 2006).

Even though several studies have been carried out on different functions of AQPs in different tissues, very few or scanty studies have been conducted in goats on the expression of AQP3 gene and its osmoregulatory role in skin. The variations in the gene expression of the native breeds thriving at arid and semiarid regions need to be studied to understand the mechanism involved for less water consumption as compared to other breeds. This leads to a better understanding and exploitation of full genetic potential of native goat breeds of India to develop new strains or breeds through the introduction of genes responsible for temperature resistance and higher water efficiency, thus sustaining the livestock productivity in coming decades of climate change. Sirohi and Barbari are the most adapted breeds in arid and semiarid, respectively. Keeping all in consideration, the present study was designed to investigate the expression of AQP3 in the skin fibroblast cells of the Barbari and Sirohi goat and its variation in the expression during hyperosmotic stress conditions in different temperatures.

\section{Materials and Methods}

\section{Fibroblast cell culture and treatment}

Skin explants were collected from the three adult Barbari and Sirohi goats and the skin fibroblasts culture were established in the laboratory. The fibroblasts were sub-cultured in Dulbecco's Modified Eagle's medium (Sigma Aldrich, USA) supplemented with 20\% Fetal Bovine Serum (FBS) (Sigma Aldrich, USA) and $1 \%$ Penicillin- Streptomycin antibiotic solution (Himedia, Mumbai) at $37{ }^{\circ} \mathrm{C}$ and $5 \% \mathrm{CO}_{2}$. Upon confluency, the fibroblast cells were passaged using $0.25 \%$ trypsin - EDTA solution (Thermofischer scientific, USA) at a split ratio of 1:3. The skin fibroblasts obtained after $4^{\text {th }}$ passage were used for the different treatments. These fibroblast cell samples were treated at 3 different temperatures at two different osmotic concentrations. Briefly, samples of two breed was divided into 5 groups and treated as follows:

\section{Treatment 1}

The cell culture flask was incubated at $25^{\circ} \mathrm{C}$ in the $\mathrm{CO}_{2}$ incubator for 3 hours. These cells were grown in cell culture media containing 20\% FBS (Sigma Aldrich, USA) and $1 \%$ penicillinstreptomycin- amphotericin B solution (Himedia, Mumbai).

\section{Treatment 2}

The cell culture flask was incubated at $37^{\circ} \mathrm{C}$ in the $\mathrm{CO}_{2}$ incubator for 3 hours. These cells were grown in cell culture media containing 20\% FBS (Sigma Aldrich, USA) and $1 \%$ penicillinstreptomycin- amphotericin B solution (Himedia, Mumbai).

\section{Treatment 3}

The cell culture flask was incubated at $42^{\circ} \mathrm{C}$ in the $\mathrm{CO}_{2}$ incubator for 3 hours. These cells were grown in cell culture media containing 20\% FBS (Sigma Aldrich, USA) and $1 \%$ penicillinstreptomycin- amphotericin B solution (Himedia, Mumbai).

\section{Treatment 4}

The cell culture flask was incubated at $37^{\circ} \mathrm{C}$ in the $\mathrm{CO}_{2}$ incubator for 3 hours. These cells were grown in Hyperosmotic cell culture media containing 20\% FBS (Sigma Aldrich, USA) and $1 \%$ penicillin- streptomycin- amphotericin B solution (Himedia, Mumbai).

\section{Treatment 5}

The cell culture flask was incubated at $42^{\circ} \mathrm{C}$ in the $\mathrm{CO}_{2}$ incubator for 3 hours. These cells were grown in Hyperosmotic cell culture media containing 20\% FBS (Sigma Aldrich, USA) and $1 \%$ penicillin- streptomycin- amphotericin B solution (Himedia, Mumbai).

$100 \mathrm{mM} \mathrm{NaCl}$ was added to the normal culture medium to simulate hyperosmotic (dehydration) condition in cells. The samples (three each) for two breed were treated in triplicate at each treatment.The skin fibroblast cells in normal culture medium at $37^{\circ} \mathrm{C}$ were taken as the control sample.

\section{RNA isolation and RT- PCR}

Total RNA was isolated from the treated skin fibroblast cells by miRNeasy kit (Qiagen,U.S). RNA concentrations were measured by Nanoquant and those RNA samples isolated from the fibroblast cells having purity between 1.9 and 2.0 using Tecan's i-control software were only used further for cDNA synthesis. The quality and integrity of the obtained RNA was analysed by $1.5 \%$ agarose gel electrophoresis. First strand cDNA was prepared by using Thermoscientific RevertAid First Strand cDNA Synthesis kit. 
Relative expression of mRNA of AQP3 gene was measured by quantitative real time-PCR (qPCR) using SYBR ${ }^{\circledR}$ Green qPCR kit. A master mix was prepared as per the following components: Maxima SYBR Green qPCR Master Mix $(2 X)-5 \mu 1$, reverse primer - $0.5 \mu \mathrm{l}$, forward primer $-0.5 \mu \mathrm{l}$, cDNA sample $-2 \mu \mathrm{l}$ and nuclease free water - $2 \mu \mathrm{l}$. Before performing Real time PCR, optimum annealing temperatures for AQP3 gene and GAPDH (housekeeping gene) were determined by carrying out gradient $\mathrm{PCR}$ of $55^{\circ} \mathrm{C}$ to $65^{\circ} \mathrm{C}$ temperature range. The sequence information of gene was retrieved from NCBI database and suitable primers were designed using primer 3 web interfaces. The primer sequence and annealing temperature of the genes are given in Table 1.

\section{PCR reactions were performed using following protocol}

$\left(50^{\circ} \mathrm{C} \mathrm{X} 2 \mathrm{~min} ; 95^{\circ} \mathrm{C}\right.$ X 10 min-Initial denaturation) $\mathrm{X} 1$ cycle; $\left(95^{\circ} \mathrm{C}\right.$ X $30 \mathrm{~s}$ - denaturation; $\mathrm{T}_{\mathrm{m}}$ of gene X $30 \mathrm{~s}$ - annealing; $72^{\circ} \mathrm{C}$ $\mathrm{X} 30 \mathrm{~s}$-elongation) X 25 cycles; $\left(95^{\circ} \mathrm{C}\right.$ X $1 \mathrm{~min} ; 55^{\circ} \mathrm{C}$ X $30 \mathrm{~s} ; 72^{\circ} \mathrm{C}$ X 30 s) X 1 cycle. Amplification Plots and Dissociation Curve for all reactions were analyzed for the presence of primer dimers or secondary structures or non-specific amplification. The relative expression of AQP3 was analyzed using $2^{\prime \Delta \Delta} \mathrm{Ct}$ method by keeping GAPDH as the reference gene and $37^{\circ} \mathrm{C}$ in normal culture medium as the control sample (Farhadi et al., 2018; Livak \& Schmittgen, 2001).

\section{Statistical analysis}

The statistical significance of variations in mRNA expression of the AQP3 gene in different breeds during different treatments was assessed by two-way ANOVA. A difference with value $\mathrm{P}<0.05$ was considered statistically significant.

\section{Results and Discussion}

To the best of our knowledge, no study has been undertaken to give an insight about the expression of AQP3 gene in skin fibroblast cells of goats and their variation in relative expression during hyperosmotic stress. The current in-vitro study was performed to know the relative mRNA expression of AQP3 gene in different breeds. This will give an insight about the molecular mechanism by which the body reacts to it at various temperature and hyperosmotic conditions. The present in-vitro study was performed in skin fibroblast cells of Barbari and Sirohi breeds and the conditions in treatment 2 was considered as the optimum conditions for the normal cell expression.

\section{RNA integrity and purity}

The RNA isolated from the fibroblast cells has purity between 1.9 and 2.0 indicative of good quality RNA as optical density (OD) 260/280 ratio is greater than 1.8. The integrity of RNA sample from fibroblasts was checked by running on $1.5 \%$ agarose gel. The integrity of the isolated RNA samples illustrated two distinct bands, one for $18 \mathrm{~S}$ and other for $28 \mathrm{~S}$ of RNA.

\section{Gene expression analysis}

The relative expression of $m R N A$ for AQP3 gene of Barbari and Sirohi breeds during different treatments is presented in Table 2 and Fig 1. Relative expression of AQP3 gene in treatment 2 was taken as the calibrator.

\section{Expression of mRNA of AQP3 gene}

The relative mRNA expression of AQP3 gene in Barbari breed was observed to be lower meanwhile in Sirohi breed the relative expression of AQP3 mRNA was slightly increased. However in both the breeds of goat, the variations in the relative expression of AQP3 mRNA during treatment 1 were observed to be nonsignificant $(\mathrm{P}>0.05)$.

The relative mRNA expression of AQP3 gene was found to be lower in Barbari breed. The relative mRNA expression of AQP3 gene in Sirohi breed was observed to be higher and statistically significant $(\mathrm{P}<0.01)$.

In both the breeds, the relative expression of AQP3 mRNA was found to be increased significantly $(\mathrm{P}<0.05)$ during treatment 4 (Table 2). However, the mRNA expression value was significantly higher $(\mathrm{P}<0.01)$ in Sirohi breed compared to the Barbari breed.

The relative expression of AQP3 mRNA in Barbari breed and Sirohi breed are presented in Table 2 and Figure 1 respectively. The relative expression of AQP3 mRNA in Sirohi breed was found to have increased significantly $(\mathrm{P}<0.01)$ though a decreased mRNA expression of AQP3 gene was seen in Barbari breed.

During treatment 1, 3, 4 and 5, the skin fibroblast cells of goat experienced stress as they were altered from the normal cell conditions for their optimum expression. The relative mRNA expression of the AQP3 gene in Barbari breed was found to be lower as compared to the Sirohi breed. Both Barbari and Sirohi breed showed a similar trend of increased relative mRNA

Table 1 Gene transcripts, primer sequence ( $5^{\prime}$ to $\left.3^{\prime}\right)$ and their product size (bp)

\begin{tabular}{llllll}
\hline S. No & Primer & F/R & Sequence $\left(5^{\prime}\right.$ to $\left.3 '\right)$ & Tm $\left({ }^{\circ} \mathrm{C}\right)$ & Product size. $(\mathrm{bp})$ \\
\hline 1 & AQP 3 & $\mathrm{~F}$ & CTTGGCTCAGACTCTGGGAGCCT & 58 & 131 \\
& & $\mathrm{R}$ & GTGGCAAAGATGCCAGCTGTGCCATT & & \\
2 & GAPDH & $\mathrm{F}$ & CCAACGTGTCTGTTGTGGATCTGA & 62 & 218 \\
& & $\mathrm{R}$ & GAGCTTGACAAAGTGGTCGTTGAG & & \\
\hline
\end{tabular}


Fig. 1 The relative mRNA expression analysis of AQP5 gene by quantitative polymerase chain reaction ( $\mathrm{qPCR}$ ) in skin fibroblast cells of Barbari and Sirohi breeds of goat during different treatment conditions $(1,2,3,4$ and 5$)$ in in-vitro studies. Different superscripts denote statistically different values $(\mathrm{P}<0.05)$ in comparison to treatment 2.

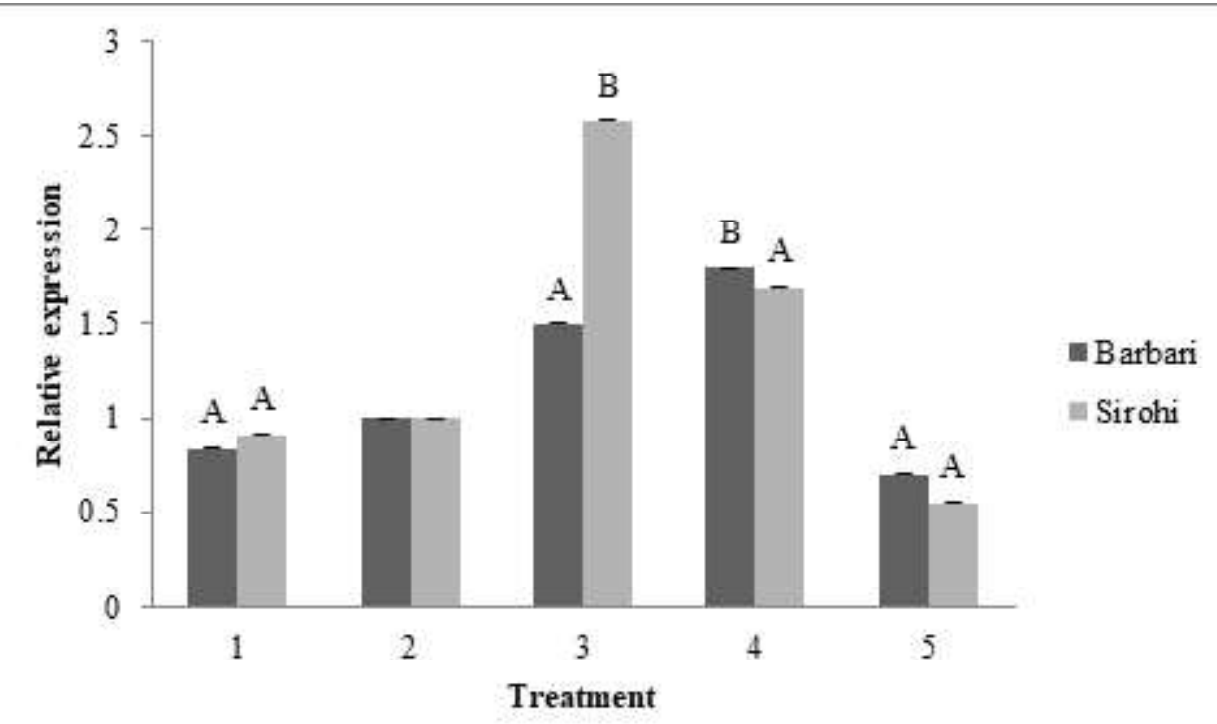

Table 2 Relative AQP3 gene expression in fibroblast cells during different treatment conditions

\begin{tabular}{llllll}
\hline & \multicolumn{5}{c}{ AQP3 gene } \\
\cline { 2 - 6 } Treatment & 1 & 2 & 3 & 4 & 5 \\
Barbari & $0.37^{\mathrm{A}} \pm 0.06$ & $1.0 \pm 0$ & $0.59^{\mathrm{A}} \pm 0.04$ & $2.23^{\mathrm{B}} \pm 0.90$ & $0.71^{\mathrm{A}} \pm 0.04$ \\
Sirohi & $1.08^{\mathrm{A}} \pm 0.04$ & $1.0 \pm 0$ & $8.77^{\mathrm{C}} \pm 0.87$ & $11.72^{\mathrm{D}} \pm 0.99$ & $3.50^{\mathrm{B}} \pm 0.75$ \\
\hline
\end{tabular}

${ }^{\mathrm{ABC}}$ Bars with different superscripts are significantly different $(\mathrm{p}<0.05)$ between Treatments

expression during treatment 3 (normal temperature and hyperosmotic condition). A significantly $(\mathrm{P}<0.01)$ higher increase in relative mRNA expression of the $\mathrm{AQP} 3$ gene was observed in Sirohi breed with increase in temperature and osmotic concentration. But the increase in the AQP3 relative mRNA expression in treatment 5 (high temperature and hyperosmotic condition) was lower as compared to the treatment 3 (normal temperature) and treatment 4(normal temperature and hyperosmotic condition). During hyperosmotic treatment of Barbari skin fibroblast cells, there was a significant increase $(\mathrm{P}<0.05)$ in the relative expression of AQP3 mRNA at normal temperature and a decline in the relative expression at higher temperature.

At higher temperature, relative mRNA expression of AQP3 gene was observed to be increased in Sirohi breed as compared to Barbari. The increased relative mRNA expression of AQP3 in the Sirohi breed may be an adaptive mechanism developed by the animal to maintain its subcutaneous hydration during high temperature and hyperosmotic stress conditions. AQP3 results in the expression of membrane channel protein that selectively transports water and glycerol in epidermis (Sougrat et al. 2002). Subcutaneous skin hydration, glycerol and water permeabilities of epidermis were reported to be decreased in AQP3 null mice (Ma et al. 2002).

Increased relative mRNA expression of AQP3 may also play a role in early keratinocyte maturation in the Sirohi breed as AQP3 acts as glycerol transporter across the cell. The glycerol is utilized for the production of phosphatidyl glycerol which in turn excites an effector enzyme for the expression of early keratinocyte differentiation markers in rapidly dividing cells of the skin in epidermis (Bollag et al. 2007). Increased keratinocytes in the skin of Sirohi goat may act as a protective mechanism for Sirohi breed from heat stress in arid regions, thus indirectly reducing the water loss. There was an increased relative expression of AQP3 mRNA in both Sirohi and Barbari goats during dehydration (hyperosmotic stress) at normal body temperature meanwhile during higher temperature combined with hyperosmotic stress, the relative expression of AQP3 was found to be reduced. This may be due to the reason that with the upregulation of AQP3 along with the physiological mechanisms of the body, the animal may be able to overcome the hyperosmotic stress at normal body temperature. AQP3 expression was observed to be increased more than two fold times in keratinocyte cultures of humans during hyperosmolar conditions (Sugiyama et al. 2001). Previous studies have reported that the expression of AQP3 in non-keratinized embryonic skin helps in regulating the transepidermal water transport (Agren et al. 2003). AQP3 also transports small solutes such as urea along with water and glycerol across the cell. This characteristic of AQP3 gene may be playing a major role during hyperosmotic stress in the arid adapted breeds during dehydration resulting in their increased expression in Sirohi breed. But during hypertonic stress at higher temperature, AQP3 gene shows a decline in their relative expression. This may be due to 
the fact that the cell may have adapted to stress or other mechanisms might have played a role.

\section{Conclusions}

The present study concluded that the mRNA expression of AQP3 gene is generally breed specific as there were variations in their relative mRNA expression patterns. This may be attributed to their difference in their adaptability to water stressed conditions. Among the two breeds studied, the Sirohi breed was found to have higher AQP3 mRNA expression indicative of high tolerance in the water deficit areas especially in arid areas. The relative expression of AQP3 mRNA was highly varying during different temperature treatments and osmotic treatments. And it may be due to its role played in transport of solutes especially glycerol along with water. Since experiments on AQP3 gene expression were done in vitro, more detailed studies (in vivo) are further required to explain more role of $\mathrm{AQP}$ gene physiology in the goat breeds.

\section{Acknowledgments}

Financial help from the Indian Council of Agricultural Research (ICAR)- Indian Institute of Water Management, Bhubhaneswar, Government of India through Agri-CRPon water project (Project Code: 1007620) is duly acknowledged. The authors are thankful to the Director of Central Institute for Research on Goats (CIRG), Uttar Pradesh, India, Director of The Central Sheep and Wool Research Institute (CSWRI), Avikanagar, Rajasthan, India and to the Vice-Chancellor, National Dairy Research Institute (NDRI), India, for providing the necessary infrastructure facility for conducting this research work.

\section{References}

Agre P, King LS, Yasui M, Guggino WB, Ottersen OP, Fujiyoshi Y (2002) Aquaporin water channels - from atomic structure to clinical medicine. J Physiol 542: 3-16.

Agre P, Kozono D (2003) Aquaporin water channels: molecular mechanisms for human diseases. Eur J Biochem 555: 72-78.

Agren J, Zelenin S, Hakansson M, Eklof AC, Aperia A, Nejsum LN, Nielsen S, Sedin G (2003) Transepidermal water loss in developing rats: role of aquaporins in the immature skin. Pediatr Res 53: 558-565.

Alamer M (2010) Effect of water restriction on thermoregulation and some biochemical constituents in lactating Aardi goats during hot weather conditions. Journal of Basic and Applied Scientific Research 11: 189-205.

Amenu K, Markemann A, Roessler R, Schultze MS, Abebe G, Zárate AV (2013) Constraints and challenges of meeting the water requirements of livestock in Ethiopia: cases of Lume and Siraro districts. Trop Anim Health Prod 45: 1539-1548.

Avendaño-Reyes L. Heat stress management for milk production in arid zones. In: Narongsak Chaiyabutr (Eds.) Milk production - an up-todate overview of animal nutrition, management and health. IntechOpen, London, U.K. 2012. Chapter 9, pp.165-184. https:// doi. org/10.5772/512997.

Bollag WB, Xie D, Zhong X, Zheng X (2007) A potential role for the phospholipase D2-aquaporin-3 signaling module in early keratinocyte differentiation: Production of a novel phosphatidyl glycerol lipid signal. J Investig Dermatol 127: 2823-2831.

Boury-Jamot M, Sougrat R, Tailhardat M, Le Varlet B (2006) Expression and function of aquaporins in human skin: Is aquaporin-3 just a glycerol transporter? Biochim Biophys Acta 1758: 1034-1042.

Farhadi E, Mahmoudi M, Rahmani F, Yousefi B, Sarafnejad A, Kavosi H, Karimizadeh E, Jamshidi A, Gharibdoost F (2018). Attenuation of aquaporin 3 and epidermal growth factor receptor expression and activation in systemic sclerosis dermal fibroblasts. $J$ Cell Physiol. 2018; 234: 12876- 12883. Doi: https://doi.org/10.1002/ jcp. 27952

Johansson I, Karlsson M, Johanson U, Larsson C, Kjellbom P (2000) .The role of aquaporins in cellular and whole plant water balance. Biochim Biophys Acta 1465: 324-42.

King LS, Kozono D, Agre P (2004) From structure to disease: the evolving tale of aquaporin biology. Nat Rev Mol Cell Biol 5: 687-98.

Livak KL and Schmittgen TD (2001). Analysis of Relative Gene Expression Data Using Real-Time Quantitative PCR and the 2"ב̈̈̆C Method. Methods. 25(4); 402-408. Doi: https://doi.org/10.1006/ meth.2001.1262

Ma T, Hara M, Sougrat R, Verbavatz JM, Verkman AS (2002) Impaired stratum corneum hydration in mice lacking epidermal water channel aquaporin-3. J Biol Chem 277: 17147-17153.

Molden D, Oweis T, Steduto P, Bindraban P, Hanjra M, Kijne J (2010) Improving agricultural water productivity: Between optimism and caution. Agricultural water Management.97:528-535.http:// dx.doi.org/10.1016/j.agwat.2009.03.023

Schaffner AR (1998) Aquaporin function, structure and expression: are there more surprises to surface in water relations? Planta 204: 1319.

Sejian V, Maurya VP, Kumar K, Naqvi SMK (2012) Effect of multiple stresses (thermal, nutritional and walking stress) on the reproductive performance of Malpura ewes. Vet Med Int. DOI:10.1155/2012/ 471760 .

Sougrat R, Morand M, Gondran C, Barre P, Gobin R, Bonte F (2002) Functional expression of AQP3 in human skin epidermis and reconstructed epidermis. J Investig Dermatol 118: 678-85.

Sugiyama Y, Ota Y, Hara M, Inoue S (2001) Osmotic stress upregulates aquaporin-3 gene expression in cultured human keratinocytes. Biochim Biophys Acta 1522: 82-88

UNESCO (2012). The United Nations World Water Development Report 4: Managing Water under Uncertainty and Risk: Executive Summary. France 